\title{
TAXONOMICAL AND CHOROLOGICAL NOTES 1 (1-19)
}

\author{
Zoltán BARINA ${ }^{1}$, Lajos BENEDEK ${ }^{2}$, Lajos Boros ${ }^{3}$, Bálint DimA ${ }^{4,5}$, \\ Ádám Folcz ${ }^{6}$, Gergely KIrÁlY ${ }^{7}$, Attila KosZKA ${ }^{8}$, Ákos MALATINsZKY ${ }^{9}$, \\ Dávid PAPP ${ }^{10}$, Dániel PIFKÓ ${ }^{11}$ and Viktor PAPP ${ }^{12}$ \\ ${ }^{1}$ Department of Botany, Hungarian Natural History Museum, \\ H-1476 Budapest,.Pf. 222, Hungary; barina@bot.nhmus.hu, ${ }^{11}$ pifko@bot.nbmus.hu \\ ${ }^{2}$ Department of Botany and Soroksár Botanical Garden, Corvinus University of Budapest, \\ H-1518 Budapest,.Pf. 53, Hungary; lajos.benedek@uni-corvinus.hu, ${ }^{12}$ viktor.papp@uni-corvinus.hu \\ ${ }^{3}$ Pro Mikológia Alapitvány, H-1142 Budapest, Ungvár u. 43, Hungary; boroslajos476@gmail.com \\ ${ }^{4}$ Plant Biology, Department of Biosciences, University of Helsinki, \\ P. O. Box65,00014 Helsinki, Finland; dima.balint@helsinki.fi \\ ${ }^{5}$ Eötvös Loránd University, Institute of Biology, Department of Plant Anatomy, \\ H-1117 Budapest, Pázmány Péter sétány 1/c, Hungary; cortinarius1@gmail.com \\ ${ }^{6}$ Educational Forestry Management Co., \\ H-9400 Sopron, Honvéd u. 1, Hungary; folczadam@gmail.com \\ ${ }^{7}$ Institute of Silviculture and Forest protection, University of West Hungary, \\ H-9400Sopron,AdyE.u. 5, Hungary; kiraly.gergely@emk.nyme.hu \\ ${ }^{8} \mathrm{H}-8060$ Mór, Arpád u.47, Hungary; attila.koszka@hotmail.com \\ ${ }^{9}$ Institute of Nature Conservation and Landscape Management, Szent István University, \\ H-2103 Gödöllö, Páter K. u. 1, Hungary; malatinszky.akos@mkk.szie.hu \\ ${ }^{10}$ Department of Pomology, Corvinus University of Budapest, \\ H-1518 Budapest,.Pf. 53, Hungary; david.papp@uni-corvinus.hu
}

Barina, Z., Benedek, L., Boros, L., Dima, B., Folcz, Á., Király, G., Koszka, A., Malatinszky, Á., Papp, D., Pifkó, D. \& Papp, V. (2015): Taxonomical and chorological notes 1 (1-19). - Studia bot. hung. 46(2): 205-221.

\begin{abstract}
The first part of the newly launched series includes miscellaneous new records from fungi to vascular plants. New chorological records of 14 fungi taxa are provided here: two new (Hypoxylon ticinense and Amylostereum laevigatum) and one confirmed (Sarcodontia crocea) for Hungary; one new for Kiskunság and Bükk Mts (Pholiota squarrosoides); five new for Vértes Mts (Arrhenia rickenii, Dentipellis fragilis, Entoloma zuccherellii var. pluteisimilis, Gomphidius roseus, Leucoagaricus ionidicolor) and partly Central Hungary; four new for Sopron Mts (Agaricus bohusii, Amanita vittadinii, Hericium erinaceus and Leccinum variicolor); and two new for Neusiedl Hills (Gomphidius roseus and Polyporus umbellatus). Records of one moss (Anacamptodon splachnoides) new for Cserhát and Cserehát Mts are provided here. New chorological records of two vascular plants are provided: one taxon (Crataegus rosaeformis subsp. curvisepala) new for Hernád Valley and NE Hungary; one (Epipactis leptochila subsp. neglecta) new for the Börzsöny Mts. Two new combinations in genus Chamaecytisus are proposed here (Chamaecytisus supinus subsp. aggregatus and subsp. pannonicus). The present paper includes also the revision of the occurrence of Calamagrostis villosa in Hungary and concludes that it has been extinct in the country.
\end{abstract}

Key words: bryophyte, extinct, fungi, Hungary, new combination, red list, vascular plant 


\section{INTRODUCTION}

With this paper, a new series is launched which includes chorological, nomenclatural, and taxonomic notes for all groups of algae, fungi, cryptogams and phanerogams. From general notes to minor comments about the taxonomy, nomenclature and typification of taxa is the subject of this series. Remarkable notes on the chorology of taxa and distributional records newly reported for at least regional level (cf. MolnÁR et al. 2008) with significance at the same time are welcome. Chorological data of taxa new, e.g. for a settlement's surroundings, or of widely distributed species but (apparently) not reported from smaller areas are not included in this series, as well as single occurrence reports of taxa without the clear description of the significance of the new report.

Our aim is to provide valuable, clear, and interpretable amendments for flora guides, monographs, and scientific papers and to avoid the loss of scattered information on the knowledge of biodiversity.

\section{MATERIAL AND METHODS}

Records of discussed taxa are in order following main taxonomic units and arranged alphabetically within them.

Specimen records are divided into two parts separated with semicolon: 1) locality data, including the names of country, region(s), settlement and toponym(s), followed by the coordinates in degrees (up to 5 decimals); 2) voucher data, including the collector(s), date of collecting/observing, acronym of herbarium (following Thiers 2015+), voucher ID, and the name of person who identified the specimen (if differs from the collector).

Denomination of biogeographical regions for Hungary follows MOLNÁR et al. (2008). Nomenclature of plant communities follows BORHIDI (2003).

\section{NEW RECORDS WITH ANNOTATIONS}

\section{Fungi}

\section{(1) Agaricus bohusii Bon (Agaricaceae)}

Hungary, Soproni-hegység (Sopron Mts): Botanical Garden of the University of West Hungary, Sopron, on soil covered by wood-chips, $47.68022^{\circ} \mathrm{N}, 16.57478^{\circ} \mathrm{E}$; leg. Z. Börcsök and Á. Folcz, 05.09 . 2013, BP 107390. - Hungary, Soproni-hegység (Sopron Mts): Várisi-forest, Quercetum petraeae-cerris, soil near Quercus wood stock, $47.68022^{\circ} \mathrm{N}, 16.5747^{\circ} \mathrm{E}$; leg. A. Hajnal, 15.07.2015, s.n. (det. Á. Folcz).

BoHus (1971) identified this species as Agaricus elvensis sensu Cooke, which was a misapplied name of $A$. elvensis Berk. et Broome. However, the latter represents a later synonym of Echinoderma asperum (Pers.) Bon, therefore the new 
name, $A$. bohusii was introduced by Bov $(1981,1983)$ for $A$. elvensis sensu Bohus. This species is characterised by cespitose appearance, which is rather unusual in the genus Agaricus (BoHus 1995). Agaricus bohusii is uncommon in Hungary (e.g. BABos 1989) and it has been protected by law since 2013 (MK 2013). The species is reported for the first time from the Sopron Mts; however, it is known in the adjoining Rosalia Mts (Austria) (DÄMoN et al. 2015).

\section{Á. Folcz}

\section{(2) Amanita vittadinii (Moretti) Vittad. (Amanitaceae)}

Hungary, Soproni-hegység (Sopron Mts): Harka, wooded pasture, $47.65067^{\circ} \mathrm{N}, 16.58643^{\circ} \mathrm{E}$; leg. B. Varga and Á. Folcz, 04.08.2014, BP 107396. - Hungary, Vértes Mts, Csákberény, Madzag-rét, extensive pasture (sheep-walk), in fairy rings; leg. A. Koszka, 30.10.2013, BP 106911.

Amanita vittadinii can typically be found in grasslands, and it is characterised by the rough warts on the pileal surface, and the concentrically arranged scales on a solid stipe without volva (BAS 1969). In Europe and North Africa it was reported from nitrophilous grasslands, open grassy areas and parks, sandy pastures, and abandoned agricultural fields. It prefers Mediterranean or subMediterranean areas (GALLI 2001), therefore it is absent in North Europe. In some regions of Hungary, $A$. vittadinii is not so rare yet, but with giving up the traditional grazing it may become endangered (SILLER et al. 2006). Herein, it is reported from the Sopron Mts and the Vértes Mts for the first time.

\section{Á. Folcz and A. Koszka}

\section{(3) Amylostereum laevigatum (Fr.) Boidin (Amylostereaceae)}

Hungary, Bakony Mts: Szentgáli Tiszafás (common yew stand of Szentgál), on the bark of living Taxus baccata L., $47.11109^{\circ}$ N, $17.78674^{\circ}$ E; leg. V. Papp, 20.07.2013, BP 106912.

The wood-inhabiting basidiomycete, Amylostereum laevigatum is a symbiont of wood wasps and it is growing mainly on Juniperus and Taxus trees. Among the European Amylostereum species, A. laevigatum is characterised by monomitic hyphal system and resupinate basidiome (BERNICCHIA and GORJón 2010). In Europe it is relatively common and widespread, however, it was not reported from Hungary. The first Hungarian record of this species is published here from the common yew stand of Szentgál.

\section{Papp}

\section{(4) Arrhenia rickenii (Hora) Watling (Tricholomataceae)}

Hungary, Vértes Mts: Pusztavám, Lépa-kút, roadside covered with Barbula unguiculata Hedw., on calcareous soil; leg. A. Koszka, 10.10.2015, BP 106913.

This small omphalinoid species is characterised mainly by strongly intervenose, relatively thick, vein-like lamellae; translucently striate pileus with a crenu- 
late margin; and by its typical habitat, growing always among mosses, mostly with Barbula spp. (ElBORNe 2012). Earlier it was classified into the genus Omphalina (Hora 1960), but the parasitic relationship with mosses and the reduced lamellae justified that the species belongs to the genus Arrhenia (WATling 1988). Until now, only one unvouchered occurrence has been published from Hungary from the easternmost part of the country at Bátorliget (LENTI 2007); however, the potential habitat (rocky path sides in calcareous soil, covered with moss) of this species is common in the country. The small, thin, fragile fruit-bodies of $A$. rickenii are hardly noticeable, and easily overlooked. According to this, it is hypothesised to be much more frequent in Hungary than it is suggested by the two data.

\section{A. Koszka}

\section{(5) Dentipellis fragilis (Pers.) Donk (Hericiaceae)}

Hungary, Vértes Mts: near Csákberény, Juhdöglö-völgy Forest Reserve, on unknown hardwood log, $47.38054^{\circ} \mathrm{N}, 18.33027^{\circ} \mathrm{E}$; leg. V. Papp, 09.09.2014, BP 106907.

The resupinate, hidnoid fungus, Dentipellis fragilis is characterised by monomitic hyphal system, presence of gloeocystidia and ornamented amyloid, globose to ovoid basdiospores (BERNICCHIA and GoRJón 2010). It is one of the twenty-one fungal species, which have been selected as indicator of the value of natural beech forests in Europe (CHRISTENSEN et al. 2004). The first data of this species from Hungary were published by SILLER (2004) from Kékes (Mátra Mts, North Hungary) and Öserdő (Bükk Mts, North Hungary) montane beech forest reserves. In addition, D. fragilis was only known from the Örség National Park (Western Transdanubia) in Hungary (SILLER et al. 2013). Herein the first record of this peculiar species is published from Central Transdanubia (Juhdöglö-völgy Forest Reserve, Vértes Mts).

V. Papp

(6) Entoloma zuccherellii var. pluteisimilis (Noordel. et C. E. Hermos.) V. Papp (Entolomataceae)

Hungary, Vértes Mts: near Csákberény, Juhdöglö-völgy Forest Reserve, on Fagus sylvatica L. log; leg. V. Papp, 30.11.2012, BP 106908 (det. V. Papp and B. Dima).

The lignicolous agaric, Entoloma pluteisimilis (Agaricales, Basidiomycota) was described from Spain and characterised by small, thin-walled, polygonal spores (NoORDELOos 2004). Former phylogenetic study (Co-DAvid et al. 2009) and a recent preliminary multigene ML (maximum-likelihood) analysis (Papp and Dima, unpublished) also indicated that the earlier described E. zuccherellii (Noordel. and Hauskn.) Noordel. et Co-David (Noordeloos 2000) and E. pluteisimilis have low genetic difference, thus the latter was suggested to belong to the morphological variety of E. zuccherellii (PAPP 2015). 
The only known Hungarian locality of E. zuccherellii var. pluteisimilis (as $E$. pluteisimilis) has been the Fényi-erdő forest (near Bátorliget, Northern Hungary) published by Noordeloos and Haus KneCHT (2009). Herein, the second Hungarian record of this taxon is presented from the Juhdöglö-völgy Forest Reserve (Vértes Mts, Central Transdanubia).

V. Papp and B. Dima

(7) Gomphidius roseus (Fr.) Fr. (Gomphidiaceae)

Hungary, Fertőmelléki-dombsor (Neusiedl Hills): Dudlesz, Pinus sylvestris L. stand, $47.71858^{\circ} \mathrm{N}$, $16.57312^{\circ}$ E; leg. A. Hajnal and Á. Folcz, 07.10.2013, s.n.; and $47.73197^{\circ} \mathrm{N}, 16.57021^{\circ} \mathrm{E}$; leg. Á. Folcz, 14.10.2013 and 18.09.2014, BP 107389. - Hungary, Vértes Mts: Pusztavám, Lépa-kút, abandoned colliery, in Pinus sylvestris plantation established on mining waste, between Suillus bovinus (L.) Roussel fruit-bodies; leg. A. Koszka, 19.10.2012, BP 106914.

Gomphidius roseus is easily recognisable by its bright red cap cuticle, whitish pileal flesh, and by the distant and decurrent lamellae, which turn from white to dark grey with age (KNUDSEN and TAYLOR 2012). There is a close association between Pinus sylvestris, Suillus bovinus and Gomphidius roseus. The relationship is considered to be parasitic (OLsson et al. 2000). The species is widespread in Europe (especially in the Northwest), moreover, locally common in some places (KRIEGLSTEINER 2000). In Hungary it is rare, only detected along the western border of the country (Örség region and Sopron Mts) and two montane localities (Mátra Mts and Zemplén Mts), therefore it is protected by law (SILLER et al. 2006). The latest occurrence in the Vértes Mts was surprising, but it has been detected continuously for three years in the same plot. In this study it is also reported for the first time from Neusiedl Hills.

\section{Á. Folcz and A. Koszka}

\section{(8) Hericium erinaceus (Bull.) Pers. (Hericiaceae)}

Hungary, Soproni-hegység (Sopron Mts): Várisi-forest Cyclamen purpurascenti-Carpinetum; leg. B. Varga, 02.10.2014, BP 107387 (det. Á. Folcz).

The familiar medicinal mushroom, Hericium erinaceus can be easily identified macroscopically by the conspicuous basidiomes consisting of numerous, typically long, dangling, fleshy simple spines, which are at first white, and becoming yellowish, then brownish with age (ThongBAI et al. 2015). In Europe it grows predominantly in old-growth forests, on living, weakened trees or dead trunks of oak and beech trees (BoDDY et al. 2011, KunCA and ČILIAK 2015). Hericium erinaceus is red-listed in several European countries (DAHLBERG and Croneborg 2006), in addition it is protected in Hungary (SILLER et al. 2006). Herein, the first locality of this species is published from the Sopron Mts.

Á. Folcz 
(9) Hypoxylon ticinense L. E. Petrini (Xylariaceae)

Hungary, Kiskunság: near Ócsa, Ócsai turjános Forest Reserve, on unknown hardwood log; leg. V. Papp, 19.11.2009, BP 106915 (det. A. Hausknecht and V. Papp); and 03.08.2010, BP 106916. - Hungary, Hanság: near Bősárkány, Pintér-Hany, $47.74716^{\circ} \mathrm{N}, 17.32856^{\circ} \mathrm{E}$, on cf. Fraxinus; leg. V. Papp, 23.06.2012, BP 106917.

The peculiar ascomycete, Hypoxylon ticinense is characterised by distinctive stromata that are usually discoid, pulvinate, thick, and undulating, surrounded when immature by a bright yellow to orange fimbriate margin. In Europe it is known from Austria, Croatia, Germany, France, Italy, Slovakia, and Switzerland (Bitzer et al. 2008, Ripková and Hagara 2003). In this study H. ticinense is reported from Hungary for the first time.

V. Papp

\section{(10) Leccinum variicolor Watling (Boletaceae)}

Hungary, Soproni-hegység (Sopron Mts): Sopron, Muck, mixed Picea abies (L.) H. Karst. stand, under Betula pendula Roth, $47.65186^{\circ} \mathrm{N}, 16.52972^{\circ} \mathrm{E}$, leg. Á. Folcz, 26.09.2013, BP 107394.

The characteristic bolete, Leccinum variicolor can be recognised macroscopically by the variegated pileus and the distinct blue-green discoloration of the context of the stipe (NoORDELOOs 2015). It is associated with common birch, mostly in humid habitats (marshes and bogs). In Hungary several records of this species was known, especially from the Örség region (SILLER et al. 2006). Herein, it is reported from the Sopron Mts for the first time.

Á. Folcz

\section{(11) Leucoagaricus ionidicolor Bellù et Lanzoni (Agaricaceae)}

Hungary, Vértes Mts: Csákberény, Juhdöglö-völgy Forest Reserve, near a fallen trunk of $\mathrm{Fa}$ gus sylvatica, on humus-rich soil; leg. A. Koszka, 08.11.2015, BP 106918.

This small Leucoagaricus species is easily recognisable by its bright purple pileus with fine, appressed scales on a whitish background. The distinct erect ring on the purple stipe is also typical (BELLÙ and LANZONI 1988, CANDUSSO and LANZONI 1990). The distinction between Leucocoprinus and Leucoagaricus based on morphological characters was questioned (e.g. VELLINGA 2004). More molecular phylogenetic studies are required to set up a clear taxonomic concept about this monophyletic group. Leucoagaricus ionidicolor is a widely distributed, but a very rare species in Europe (LANGE 2012), where it was reported mainly from thermophilous forests, in humus-rich habitats or decomposed wood debris buried in the soil (HOLEC 2009). From Hungary, we have only two former data. It was found in a floodplain forest near Gyula (VASAS 2000) and a beech forest near Budapest (ALBERT 2008). Herein, the third occurrence data of this species is reported from the Juhdöglö-völgy Forest Reserve (Vértes Mts).

A. Koszka 
(12) Pholiota squarrosoides (Peck) Sacc. (Strophariaceae)

Hungary, Kiskunság: near Ócsa, Ócsai turjános Forest Reserve, on unknown hardwood log, leg. V. Papp, 05.10.2011, BP 106909. - Hungary, Bükk Mts, Öserdő Forest Reserve, on Fagus sylvatica $\log , 48.06020^{\circ} \mathrm{N}, 20.44590^{\circ} \mathrm{E}$; leg. L. Benedek, 09.27.2015, BP 106910 (det. L. Benedek and V. Papp).

The rare and protected, brown-spored agaric Pholiota squarrosoides was formerly known only from the Juhdöglö-völgy Forest Reserve in Hungary (PAPP and Dim A 2014). The morphological description and the infrageneric classification of this species were discussed by PAPP and Dima (2014). Herein, two new localities of $P$. squarrosoides are presented. The one from the Öserdő Forest Reserve is particularly interesting from the mycological point of view, considering that Öserdő is one of the most intensively studied forest reserves in Hungary (e.g. Siller 1986, 2004, Siller and Turcsányi 2002, TAKÁcs and Siller 1980).

V. Papp and L. Benedek

(13) Polyporus umbellatus (Pers.) Fr. (Polyporaceae)

Hungary, Fertőmelléki-dombsor (Neusiedl Hills): Szárhalom, Quercetum petraeae-cerris, $47.70384^{\circ} \mathrm{N}, 16.62861^{\circ} \mathrm{E}$; leg. A. Hajnal, 06.08.2014, s.n. (det. Á. Folcz).

Macroscopically it is a very distinct species within the genus Polyporus by the multiple circular pilei arising from a common stipe (RYVARDEN and MELO 2014). In Europe it is considered to be a rare species; however, in some regions of Central Europe it is reasonably widespread (e.g. DëMON et al. 2015, KunCA 2011). In Hungary, $P$. umbellatus is a protected species, despite the fact that several localities of the species are known in the country: e.g. Bükk Mts, Mátra Mts, Buda Mts, Sopron Mts, (SILler et al. 2006). Herein, the first locality of P. umbellatus is published from the Neusiedl Hills.

Á. Folcz

\section{(14) Sarcodontia crocea (Schwein.) Kotl. (Meruliaceae)}

Hungary, Zemplén Mts: Károlyfalva, $48.36340^{\circ} \mathrm{N}, 21.57908^{\circ} \mathrm{E}$, on branch of living old Malus domestica Borkh., leg. L. Boros, 16.08.2014, BP 106911 (det. V. Papp and D. Papp).

The hidnoid fungus, Sarcodontia crocea is characterised by sulphur yellow to ferruginous brown aculei, thick-walled subicular hyphae, and smooth thickwalled basidiospores (BERNicchia and Gorjón 2010, Kotlába 1953). It is a wood-inhabiting species causing white rot on mostly apple trees (Malus spp.), but it was also reported from several other tree species (Pyrus, Prunus, Sorbus, etc.) (SzCZEPKOWS Ki 2010). Previously it was described as a dangerous parasite of apple orchards (КотLÁBA 1953), but nowadays it is considered to be threatened (ING 1993), or even extinct from some regions (LÆSSøE 2004), and has no agronomic importance. The decreasing number of old apple orchards is probably in connec- 
tion with the extinction of Sarcodontia crocea (VENTURELLA 2006). Another cause might be the global climate change, which, on the contrary, results in the unexpected occurrence of the fungus in the northern regions of Europe (KREISEL 2006).

BÁNHEGYI et al. (1953) mentioned this species (as Odontia setosa) from Hungary (without occurrence data) and stated that it is not a rare species. However, studying the subsequent Hungarian literatures no data were found of Sarcodontia crocea. In this study a recent locality of $S$. crocea is published, which was found in NE Hungary in 2014. Unfortunately, this year we have experienced that the host tree was felled.

L. Boros, D. Papp, and V. Papp

Bryophytes

(15) Anacamptodon splachnoides (Froel. ex Brid.) Brid. (Amblystegiaceae)

Hungary, Cserehát, Tornaszentjakab: Csonkás, knot-hole of Turkey oak (at the border of Quercetum petraeae-cerris and Querco-Carpinetum), $48.52249^{\circ} \mathrm{N}, 20.93543^{\circ} \mathrm{E}, 225 \mathrm{~m}$; leg. Z. Barina, 17.07.2015, Nr. 28184. - Hungary, Központi-Cserhát, Pásztó: Eastern slope of Mt Tepke, knothole of Turkey oak (margin of Quercetum petraeae-cerris stand), $47.94086^{\circ} \mathrm{N}, 19.64987^{\circ} \mathrm{E}, 286 \mathrm{~m}$; leg. Z. Barina, 25.10.2015, Nr. 28480. - Hungary, Központi-Cserhát, Mátraszőlős: near the quarry of Fehérkö-bánya, in thermophilous oak woodland, knot-hole of Turkey oak, $47.977217^{\circ} \mathrm{N}$, 19.668464 E, $401 \mathrm{~m}$; leg. Z. Barina, 19.11.2015, Nr. 28490.

Anacamptodon splachnoides is a circumpolar species, rare and threatened all across Europe, and endangered also in Hungary (NÉmETH and ERZBERGER 2015). Its rarity is due to its specific habitat, as it occurs in knot-holes (dendrothelma) of trees. DAvis and PURSELL (2007) found it not uncommon in Pennsylvania (United States of America) and concluded that it is usually simply overlooked because of its specific habitat. Though it can occur on various trees, all actual records in Hungary are from moist knot-holes of Turkey oak trees. Despite the wide distribution of oak forests, only 8 actual localities of $A$. splachnoides are known in Hungary (NÉMETH and ERZBERGER 2015).

Being a characteristic species, it is easily recognisable also by non-expert bryologists. During vegetation mapping in oak zones of the North Hungarian Mountains, where actual data of the species only from the Börzsöny and Bükk Mts (SzÜcs et al. 2015), and historical data from the Mátra and Zemplén Mts and the Heves-Borsodi-dombság are known (NÉmETH and ERZBERGER 2015), two additional populations were found in the Cserhát and Cserehát Mts. Similarly to recent experiences, all new occurrences are at the margins of Quercetum petraeaecerris stands on Turkey oak. Though during our work, not $A$. splachnoides colonies were searched primarily, but based on checking a high number of knot-holes, we assume that the species is fairly rare and uncommon even in apparently suitable habitats. Since existing only one thimbleful three palm-sized colonies in the 
new localities, the overall extent of its patches is less than $0.5 \mathrm{~m}^{2}$ in Hungary, thus its red-list status seems to be well-founded.

Z. Barina

\section{Vascular plants}

(16) Chamaecytisus (Fabaceae)

LövE and Löve (1961a: 222) listed 8 new combinations in genus Chamaecytisus (Chamaecytisus albus subsp. pallidus, Ch. austriacus subsp. virescens, $C h$. blockianus, Ch. hirsutus subsp. leucotrichus, Ch. ratisbonensis subsp. elongatus, $C h$. supinus subsp. aggregatus, Ch. supinus subsp. pannonicus and Ch. supinus subsp. pseudorochelii). Soó (1966) attributed four of these combinations to Á. Löve and D. Löve (Chamaecytisus hirsutus subsp. leucotrichus (Schur) Á. Löve et D. Löve, Ch. supinus subsp. pannonicus (Simonkai) Á. Löve et D. Löve, Ch. supinus subsp. aggregatus (Schur) Á. Löve et D. Löve, and Ch. supinus subsp. pseudorochelii (Simonkai) Á. Löve et D. Löve) without any references to the relevant basionyms (years of publication of the new combinations were given only). Subsequent authors also attributed these names to Á. Löve and D. Löve: Ch. hirsutus subsp. leucotrichus (Schur) Á. Löve et D. Löve by OpREA (2005), Ciocarlan (2000, 2009), and Simon (2000), Ch. supinus subsp. aggregatus (Schur) Á. Löve et D. Löve by Simon (2000) and Pifkó (2005a, b, 2009a, b), and Ch. supinus subsp. pannonicus (Simonkai) Á. Löve et D. Löve by PIFKó (2005a, 2009b). According to the introduction, Löve and Löve (1961a: 6) had no intention to create the above new combinations (“...it should be noted, that transfers indicated by the names of the original authors in parentheses but not followed by our initials are not to be attributed to us. They represent cases to which we want to draw attention, or which may need a closer study by aid of modern methods. Also, some such taxa are left uninitiated, because we suspect that the transfers have already been made, though we have been unable to find them in the literature.") and listed the names without references for their basionym. According to the International Code of Nomenclature for algae, fungi, and plants (MCNEILL et al. 2012, ICN) due to the missing reference (Art. 41.5) and missing acceptance by the authors (ICN Art. 36.1a, b) all these Chamaecytisus combinations by Löve and Löve (1961a) are invalid (cf. PIF Kó 2015).

These eight combinations were also neglected by LövE and Löve $(1961 b, c)$, where all new combinations were published together with those from LövE and Löve (1961a) treated as valid names by them.

Later on, the combination Chamaecytisus hirsutus subsp. leucotrichus (Schur) was validly published by PONERT (1973) (treated as Ch. triflorus subsp. leucotrichus by Pifkó 2005a). The combination Chamaecytisus pseudoroche- 
lii (Simonkai) Pifkó based on Cytisus pseudorochelii was validly published by PIF Kó (2005a) for the hybrid of Ch. supinus subsp. aggregatus and Ch. austriacus (L.) Link. The combination Chamaecytisus blockianus was validly published by Czerepanov (1973). Chamaecytisus elongatus (Waldst. et Kit.) Link and Ch. virescens (Kováts ex Neilr.) Dostál are treated on species rank (cf. PIf Kó 2007). The taxonomic position of "Cytisus pallidus" is still not clear, it might belong to Chamaecytisus virescens, to Ch. rochelii or to Ch. albus (cf. PIF Kó 2007).

Two of the eight above taxa are actually accepted as subspecies within genus Chamaecytisus (cf. PIF Kó 2005a, 2009a); however, these combinations have not been published validly, thus, hereby two new combinations are proposed:

Chamaecytisus supinus subsp. aggregatus (Schur) Pifkó, comb. nov., Basionym: Cytisus aggregatus Schur, Enum. Pl. Transsilv.: 149. 1866.

Chamaecytisus supinus subsp. pannonicus (Simonkai) Pifkó, comb. nov., Basionym: Cytisus pannonicus Simonkai, Math. Term. Közlem. 22: 368. 1888.

D. Pifkó

(17) Crataegus rosaeformis Janka subsp. curvisepala (Lindm.) Kerényi-Nagy (Rosaceae)

Hungary, Hernád Valley: Hernádcéce, Berek, in the floodplain of the river Hernád, in white poplar alluvial forest; leg. Á. Malatinszky, 04.09.2013, BP 745232 (det. V. Kerényi-Nagy).

In his recent taxonomic review on the hawthorns of the Carpathian Basin KERÉNYI-NAGY (2015) described this infraspecific $(2 n=51)$ taxon: "the fruit and the corymb are bald, the stipule leaves are nail-like on their tips. The leaves are deeply and shallowly segmented". He indicates it as a mountain species throughout Europe that migrated to the Carpathian Basin from the north, and classified it as a long sepal taxon to the "Curvisepala group". His work presents this taxon only from the Bükk Mts, Pilis Mts and Vértes Mts in Hungary. Our record largely extends the known area of this taxon in Hungary. It is significant also from the aspect of its ecological claim, as this supposedly boreal taxon occurs here in a plain river valley; moreover, the fact that it was not effected by introgressive hybridisation with C. monogyna aggregate species (according to KERÉNYI-NAGY 2015 the hybrids are more common than the parental species and grow to their detriment) indicates close-to-natural ecological circumstances.

Á. Malatinszky

(18) Calamagrostis villosa (Chaix) J. F. Gmelin (Poaceae)

Calamagrostis villosa is a widespread species of mountain and subalpine regions in Central and SE Europe; it occurs mainly in acidophilus forest associations and their derivatives often as a dominant species (MEUSEL et al. 1965, CONERT 
1989, PYšEK 1993). Despite its frequency in the neighbouring mountains (the Northern and Eastern Carpathians and the Alps), the occurrence of the species has been reported from Hungary only recently. In the course of herbarium revisions in BP, Lajos Felföldy identified two (originally undetermined) specimens of C. villosa collected by Ádám Boros at a relic fen lake near Csaroda in Bereg Plain, NE Hungary (TATÁr 1995). Furthermore, Molnár (2000) described a new locality of this species from the southern part of the Nyírség region E of Debrecen, NE Hungary. The latter author also mentioned a voucher specimen collected by him and revised by L. Felföldy (deposited in BP).

During the preparation of the distribution atlas of the Hungarian flora my intention was to supervise some data of critical grasses, in this process I also reviewed the material of rare Calamagrostis species in BP. Beside the curiosity of the reported actual locality of $C$. villosa (occurrence in a lowland swamp community) I was rather sceptic on the account of some details of the morphological characterisation of the plants found near Debrecen by MOLnáR (2000): “... the plant has short rhizomes or tussocks" and "... the awn of the lemma does not arise in the middle of the back of the lemma (as in the case of C. stricta) but near the basis of the lemma". In particular, the latter remark shows a clear confusion of the distinctive features of C. stricta (Timm) Koeler and C. villosa (probably originated in the misleading key for Calamagrostis of Simon 1992).

Based on this newer revision I confirm that both historical collections of Boros (“Comit. Bereg. In ripa lacus "Nyíres-tó” prope Csaroda”, BP 405783, BP 405785; leg. Á. Boros, 19.07.1953, det. L. Felföldy 13.01.1993) apparently belong to $C$. villosa. On the contrary, the voucher of Molnár ("Comit. Hajdú, in Magnocaricetis ad ripam canalis "Bodzás-ér" iuxta praed. "Málik-tanya" inter “Akácos” et "Hosszú-dűlő" pr. opp. Debrecen”, BP 603825, leg. A. Molnár, 22.07.1999, det. L. Felföldy) proved to be misidentified and belongs to C. stricta; this fact was also strengthened by the revision label of Beata Paszko (Krakow), added on 13 December 2003. This specimen is fragmentary, consisting only two inflorescences; even so it can be identified doubtlessly on the basis of the following characters (see also the key of PENKSzA 1999):

- the lemma is as long as or slightly shorter than the glumes,

- the back of the lemma is rough at least in the upper part,

- the awn arises in the lower part of the back of the lemma (as given by MOLNÁr 2000 as well).

It is noteworthy that on this voucher the hairs of the basis of the lemma are nearly as long as the lemma which is rather not typical for C. stricta (this feature is also not present in other specimens of $C$. stricta deposited in BP), and can cause troubles by the identification. However, this symptom probably arose due to the 
unfavourable (dried, wizened) stage of the herbarium specimen examined, and it does not change the final result of the revision.

So thus, the single actual record of C. villosa in Hungary is to be deleted, the occurrence of the species has not been confirmed in the last 50 years. Its recent status on the Hungarian Red List ("Critically endangered" according to KIRÁLY 2007), should be amended to the category "Extinct".

\section{G. Király}

(19) Epipactis leptochila (Godfrey) Godfrey subsp. neglecta (Kümpel) Kümpel

Hungary, Börzsöny Mts: Diósjenő, at the foot of Mt "Málna-hegy" near the ruins of "Hárombarát vadászház", in beech forest; leg. Á. Malatinszky, 31.07.2010, s.n. (photodocumented), (det. A. Molnár V.).

Central and W European taxon, described in 1996 from Germany as a species related to E. leptochila. It is distributed from France and Belgium to Italy southwards and to Slovakia and Hungary eastwards (JAKELY and KÖNIGHOFER 2009, VLČKO et al. 2003).

The distribution of the subspecies is less known in Hungary, being an overlooked and - as its name indicates - a neglected taxon. Both KIRÁLY (2007) and Molnár (2009) discussed it under E. leptochila without giving its red list status or distribution in Hungary. On the contrary, it has been reported from the Bakony Mts (MÉszáros and Simon 2009), Vértes Mts (Riezing 2013), Gödöllő Hills (DudÁs 2011), and the Mátra Mts (SUlYoK 2012), while it seems to be one of the most common cleistogamous helleborines in the Bükk Mts and likely most of the records of E. leptochila from that region refers to subsp. neglecta (SULYOK 2011).

Epipactis leptochila has been known from only one locality in the Börzsöny Mts (far from the above locality), without indicating the subspecies (NAGY 2007), thus the subspecies is newly reported from the Börzsöny Mts and this record largely extends the species' known area in Hungary.

Á. Malatinszky

Acknowledgements - Ákos Malatinszky highly appreciate the kind help of Attila Molnár V. and Viktor Kerényi-Nagy in the determination of certain plant species. We say thanks to Viktor Virók for searching for data in the Database of the Aggtelek National Park Directorate. Work of Gergely Király was founded by “Agrárklíma.2 VKSZ-12-1-2013-0034" grant.

Összefoglaló: Jelen közleményünkben, mely egy cikksorozat első részét képezi, 19 faj (gomba, moha és edényes növény) elterjedésének és nevezéktanának ismeretéhez közlünk kiegészítéseket. 14 gombafaj új regionális adatait közöljük: kettőt újonnan közlünk Magyarország területéről (Hypoxylon ticinense és Amylostereum laevigatum), egynek (Sarcodontia crocea) pedig megerösítjük magyarországi előfordulását; egy faj új a Kiskunság területére és a Bükk hegységre (Pholiota squar- 
rosoides); öt új a Vértesre (Arrhenia rickenii, Dentipellis fragilis, Entoloma zuccherellii var. pluteisimilis, Gomphidius roseus, Leucoagaricus ionidicolor) és részben Közép-Magyarország területére; négy új a Soproni-hegységre (Agaricus bohusii, Amanita vittadinii, Hericium erinaceus and Leccinum variicolor); kettő pedig új a Fertőmelléki-dombsorra (Gomphidius roseus és Polyporus umbellatus). Egy mohafajt (Anacamptodon splachnoides) újonnan közlünk a Cserhát és a Cserehát területéröl. Két edényes növényfaj új elterjedési adatait közöljük: egy (Crataegus rosaeformis subsp.curvisepala) új a Hernád-völgyre és egyben Északkelet-Magyarország területére; egy (Epipactis leptochila subsp. neglecta) pedig új a Börzsöny területére. A Chamaecytisus nemzetségen belül két új kombinációt hozunk létre (Chamaecytisus supinus subsp. aggregatus and subsp. pannonicus). Ismertetjük a Calamagrostis villosa magyarországi előfordulásának revízióját, megállapítva, hogy a fajnak egyetlen hiteles adata származik az ország területéről és kipusztultnak tekintendő.

\section{REFERENCES}

Albert, L. (2008): Színes oldalak - Mikol. Közlem., Clusiana 47(1): 95-96.

BABos, M. (1989): Magyarország kalaposgombáinak (Agaricales s. 1.) jegyzéke I. [The Agaricales s. 1. taxa of Hungary I]. - Mikol. Közlem., Clusiana 1989(1-3): 3-234.

BÁnhegyi, J., Bohus, G., KalmáR, Z. and Ubrizsy, G. (1953): Magyarország nagygombái - a kalaposgombák kivételével. - Akadémiai Kiadó, Budapest, 368 pp.

BAs, C. (1969): Morphology and subdivision of Amanita and a monograph of its section Lepidella. - Persoonia 5: 285-579.

BeLLÙ, F. and LANZONI, G. (1988): Leucoagaricus ionidicolor sp. nov. - Riv. Micol. 31(3-4): 107-110. Bernicchia, A. and Gorjón, S. P. (2010): Corticiaceae s. l. (Fungi Europaei 12). - Candusso, Alassio, $1008 \mathrm{pp}$.

Bitzer, J., Lessøe, T., Fournier, J., Kummer, V., Decock, C., Tichy, H. V., Piepenbring, M., Peršoh, D. and Stadler, M. (2008): Affinities of Phylacia and the daldinoid Xylariaceae, inferred from chemotypes of cultures and ribosomal DNA sequences. - Mycol. Res. 112:251-270. http://dx.doi.org/10.1016/j.mycres.2007.07.004.

Boddy, L., Crockatt, M. E. and Ainsworth, A. M. (2011): Ecology of Hericium cirrhatum, H. coralloides and H. erinaceus in the UK. - Fungal Ecol. 4: 163-173.

http://dx.doi.org/10.1016/j.funeco.2010.10.001

Boнus, G. (1971): Agaricus studies III. - Annls hist.-nat. Mus. natn. hung. 63: 77-82.

BoHUs, G. (1995): Agaricus tanulmány, XIII. Európából ismertté vált Agaricus fajok és faj alatti egységek határozókulcsa. [Agaricus studies, XIII. Key to the subgenus Agaricus from Europe]. - Mikol. Közlem., Clusiana 34(1): 5-36.

Bon, M. (1981): Clé monographique des Lépiotes d'Europe (Agaricaceae, Tribus Lepioteae et Leucocoprineae). - Doc. Mycol.11(43): 1-77.

Bon, M. (1983): Novitates - Validations de taxons et combinaisons nouvelles. - Doc. Mycol. 13(49): $56-56$.

Borhidi, A. (2003): Magyarország növénytársulásai. - Akadémiai Kiadó, Budapest, 610 pp.

Candusso, M. and Lanzoni, G. (1990): Lepiota s. l. (Fungi Europaei 4). - Candusso, Saronno, Giovanna Biella, 744 pp.

Christensen, M., Heilmann-Clauswn, J., Walleyn, R. and AdamČik, S. (2004): Woodinhabiting fungi as indicators of nature value in European beech forests. In: MARCHETTI, M. (ed.): Monitoring and indicators of forest biodiversity in Europe from ideas to operationality. - EFI Proceedings 51: 229-237.

Ciocârlan, V. (2000): Flora ilustrată a României. Pteridophyta et Spermatophyta. - Ceres, Bucureşti, $1138 \mathrm{pp}$. 
CiocÂrlan, V. (2009): Flora ilustrată a României. Ed. 3. - Ceres, Bucureşti, 1141 pp.

Co-David, D., LANGeveld, D. and Noordeloos, M. E. (2009): Molecular phylogeny and spore evolution of Entolomataceae. - Persoonia 23: 147-176.

http://dx.doi.org/10.3767/003158509X480944

Conert, H.J. (1989): Calamagrostis villosa. - In: HegI, G. (ed.): Illustrierte Flora von Mitteleuropa. 3. ed., Band I, Teil 3. Paul Parey, Hamburg, pp. 365-367.

Czerepanov, S. K. (1973): Additamenta et corrigenda ad "Floram URSS" (tomi I-XXX). - Nauka, Leningrad, $668 \mathrm{pp}$.

Dahlberg, A. and Croneborg, H. (2006): The 33 threatened fungi in Europe. Convention on the conservation of European wildlife and habitats (Bern Convention). Nature and environment, No. 136. - Council of Europe Publishing, Strasbourg, 137 pp.

Dämon, W., Haus knecht, A. and Krisai-Greilhuber, L. (2015): Database offungi in Austria. - Österreichischen Mykologischen Gesellschaft, http://www.austria.mykodata.net

Davis, D. D. and Pursell, R. A. (2007): Collecting the Knot-Hole Moss (Anacamptodon splachnoides). - Evansia 24(1): 1-5. http://dx.doi.org/10.1639/0747-9859-24.1.1

DuDÁs, J. A. (2011): A Neogradense flórajárás új növényfaja és egyéb florisztikai adatok a Gödöllöidombságból. - Tudományos Diákköri Konferencia dolgozatainak összefoglalói, Szent István Egyetem, Gödöllö, p. 228.

Elborne, S. A. (2012): Arrhenia Fr. - In: KnUdsen, H. and Vesterholt, J. (eds): Funga Nordica. Vol. 2. Agaricoid, boletoid, clavarioid, cyphelloid and gastroid genera. Nordsvamp, Copenhagen, pp. 252-260.

Galli, R. (2001): Le Amanite. - Edinatura, Milano, 216 pp.

HOLEC, J. (2009): Remarks on taxonomy and ecology of Leucoagaricus ionidicolor based on a find from Central Bohemia (Czech Republic). - Mycotaxon 109: 329-336. http://dx.doi.org/10.5248/109.329

HorA, F. B. (1960): New check list of British agarics and boleti part IV. Validations, new species and critical notes. - Trans. British Mycol. Soc. 43(2): 440-459.

InG, B. (1993): Towards a red list of endangered European macrofungi. - In: PEgLER, D. N., Boddy, L., ING, B. and KIRK, P. M. (eds): Fungi of Europe: investigation, recording and conservation. Royal Botanic Gardens, Kew, pp. 231-237.

JAKelY, D. and KöNighofer, H. (2009): Neu für die Steiermark: Epipactis leptochila subsp. neglecta Kümpel, die Übersehene Schmallippen-Ständelwurz. - Joannea Botanik 7: 55-61.

KERÉNYI-NAGY, V. (2015): A Kárpát-Pannon és Illir régió vadon termő galagonyáinak monográfiája. (A monograph of hawthorns of Carpat-Pannon and Illyr regions). - Szent István Egyetem, Egyetemi Kiadó, Gödöllö, 323 pp.

Király, G. (ed.) (2007): Vörös Lista. A magyarországi edényes flóra veszélyeztetett fajai. [Red list of the vascular flora of Hungary]. - Private edition, Sopron, $73 \mathrm{pp}$.

Knudsen, H. and Taylor, A. (2012): Gomphidius Fr. - In: KnUdSen, H. and Vesterholt, J. (eds): Funga Nordica. Vol. 2. Agaricoid, boletoid, clavarioid, cyphelloid and gastroid genera. Nordsvamp, Copenhagen, pp. 198-199.

KотLÁBA, F. (1953): Nebezpecný parasit jabloní - Sarcodontia crocea (Schweinitz) comb. nov. Ceská Mykol. 7(3): 117-123.

Kreisel, H. (2006): Global warming and mycoflora in the Baltic Region. - Acta Mycol. 41(1): 79-94. http://dx.doi.org/10.5586/am.2006.012

Krieglsteiner, G. J. (2000): Die Grosspilze Baden-Württembergs. Band 2. Ständerpilze: Leisten-, Keulen-, Korallen- und Stoppelpilze, Bauchpilze, Röbrlins- und Täublingsartige. - Ulmer, Stuttgart, $620 \mathrm{pp}$. 
Kunca, V. (2011): Ecology and incidence of Polyporus umbellatus in Slovakia. - Czech Mycol. 63(1): 39-53.

KUNCA, V. and ČILIAK, M. (2015): Ecology, incidence and indication value of Hericium erinaceus in Slovakia and the Western Carpathians. - Czech Mycol. 67(1): 107.

LANGe, C. (2012): Leucoagaricus Singer. - In: Knudsen, H. and Vesterholt, J. (eds): Funga Nordica. Vol. 2. Agaricoid, boletoid, clavarioid, cyphelloid and gastroid genera. Nordsvamp, Copenhagen, pp. 637-642.

LÆssøE, T. (2004): Æblepig (Sarcodontia crocea) nu fundet i Danmark. I: Vesterholt, J. Usædvanlige danske svampefund. - Svampe 49: 40-42.

LENTI, I. (2007): A bátorligeti Fényi-erdő nagygombái. - Szabolcs-Szatmár-Beregi Szemle 42(2): 203-217.

Löve, A. and LövE, D. (1961a): Chromosome numbers of Central and Northwest European plant species. - Opera botanica (Lund) 5: 1-581.

Löve, A. and LövE, D. (1961b): Some nomenclatural changes in the European flora. I. - Bot. Notiser 114: 33-47.

Löve, A. and LövE, D. (1961c): Some nomenclatural changes in the European flora. II. - Bot. Notiser 114: 48-56.

MK (2013): A vidékfejlesztési miniszter 83/2013. (IX. 25.) VM rendelete a védett és a fokozottan védett növény- és állatfajokról, a fokozottan védett barlangok köréről, valamint az Európai Közösségben természetvédelmi szempontból jelentős növény- és állatfajok közzétételéről szóló 13/2001. (V. 9.) KöM rendelet módosításáról. [ministerial order concerning protection of nature]. - Magyar Közlöny 156: 67479-67503.

McNeill, J., Barrie, F. R., Buck, W. R., Demoulin, V., Greuter, W., Hawksworth, D. L., Herendeen, P. S., Knapp, S., Marhold, K., Prado, J., Prud'homme van Reine, W. F., SMith, G. F., Wiersema, J. H. and TuRLAND, N. J. (2012): International Code of Nomenclature for algae, fungi and plants (Melbourne Code) adopted by the Eighteenth International Botanical Congress Melbourne, Australia, July 2011. - Koeltz Scientific Books, Königstein, 240 pp.

Mészáros, A. and Simon, P. (2009): Adatok Veszprém megye flórájához I. - Kitaibelia 14(1): 69-85.

Meusel, H., JäGer, E. J. and Weinert, E. (1965): Vergleichende Chorologie der zentraleuropaischen Flora Vol. I. - Gustav Fischer, Jena, $583+258$ pp.

MolnáR, A. (2000): Calamagrostis villosa (Chaix) Gmel. Debrecen mellett. (Calamagrostis villosa (Chaix) Gmel. near Debrecen). - Kitaibelia 5: 229-230.

Molnár, A. (2009): Orchidaceae. - In: KirÁly, G. (ed.): Új magyar füvészkönyv. Magyarország hajtásos növényei. Határozókulcsok. (New Hungarian herbal. The vascular plants of Hungary. Identification key). Aggteleki Nemzeti Park Igazgatóság, Jósvafö, pp. 571-583.

Molnár, Cs., Molnár, Zs., Barina, Z., Bauer, N., Biró, M., Bodonczi, L., Csathó, A. I., CSI KY, J., DeÁK, J. Á., Fekete, G., HARmos, K., Horváth, A., IsÉpy, I., JUHÁsZ, M., KÁllayné SZerényi, J., Király, G., Magos, G., Máté, A., Mesterházy, A., Molnár, A., Nagy, J., Óvári, M., Purger, D., Schmidt, D., Sramkó, G., SzÉnÁsi, V., Szmorad, F., Szollát, Gy., TóTH, T., VIDRA, T. and Virók, V. (2008): Vegetation-based landscape-regions of Hungary. Acta Bot. Hung. 50(Suppl.): 47-58. http://dx.doi.org/10.1556/ABot.50.2008.Suppl.4

NAGY, J. (2007): A Börzsöny hegység edényes flórája. - Duna-Ipoly Nemzeti Park Igazgatóság, Budapest, $376 \mathrm{pp}$.

NÉmeth, Cs. and Erzberger, P. (2015): Anacamptodon splachnoides (Amblystegiaceae): Hungarian populations of a moss species with a peculiar habitat. - Studia bot. hung.46(1): 61-75. http://dx.doi.org/10.17110/StudBot.2015.46.1.61 
Noordeloos, M. E. (2000): Tre nuove Entolomataceae (Agaricales) dall'Italia. - Boll. Gr. Micol. "G. Bresadola" 43(3): 23-33.

Noordeloos, M. E. (2004): Entoloma s. l. Supplemento. (Fungi Europaei 5a). - Candusso, Alassio, pp. 761-1378.

Noordeloos, M. (2015): The genus Leccinum in Northern and Central Europe. - http://www. entoloma.nl/html/leccinum_eng.html (accessed: 26.10.2015).

Noordeloos, M. E. and Hausknecht, A. (2009): New and interesting Entoloma species from Central Europe. - Österr. Z. Pilzk. 18: 169-182.

Olsson, P. A., Münzenberger, B., Mahmood, S. and Erland, S. (2000): Molecular and anatomical evidence for a three-way association between Pinus sylvestris and the ectomycorrhizal fungi Suillus bovinus and Gomphidius roseus. - Mycol. Res. 104: 1372-1378. http://dx.doi.org/10.1017/S0953756200002823

Oprea, A. (2005): Lista critică a plantelor vasculare din România. - Editura Universității “Alexandru Ioan Cuza", Iaşi, 668 pp.

PAPP, V. (2015): Nomenclatural novelties. - Index Fungorum 224: 1.

PAPP, V. and DimA, B. (2014): A Pholiota squarrosoides első magyarországi előfordulása és előzetes filogenetikai vizsgálata. - özlem., Clusiana 53(1-2): 33-42.

Penksza, K. (2009): Calamagrostis Roth. - In: KirálY, G. (ed.): Új magyar füvészkönyv. Magyarország hajtásos növényei. Határozókulcsok. (New Hungarian herbal. The vascular plants of Hungary. Identification key). Aggteleki Nemzeti Park Igazgatóság, Jósvafö, pp. 529-530.

Pıf Kó, D. (2005a): Adatok a hazai Chamaecytisus-fajok ismeretéhez II. (Data to the knowledge of the Hungarian Chamaecytisus species II). - Flora Pannonica 3(1): 163-174.

PIf Kó, D. (2005b): Taxonomic revision and typification of Cytisus (Leguminosae) in the Herbarium Carpato-Pannonicum in Budapest (BP). - Annls hist.-nat. Mus. natn. hung. 97: 23-28.

Pif Kó, D. (2007): Kitaibel's Cytisus taxa. - Studia bot. hung. 38: 11-32.

PIf Kó, D. (2009a): Chamaecytisus Link. - In: KIRÁLY, G. (ed.): Új magyar füvészkönyv. Magyarország hajtásos növényei. Határozókulcsok. (New Hungarian herbal. The vascular plants of Hungary. Identification key). Aggteleki Nemzeti Park Igazgatóság, Jósvafö, pp. 239-241.

Pif Kó, D. (2009b): Schur's Cytisus taxa - Studia bot. hung. 40: 143-163.

PIfKó, D. (2015): Index of scientific names of Chamaecytisus (Leguminosae) taxa - Studia bot. hung. 46(2): 175-203. http://dx.doi.org/10.17110/StudBot.2015.46.2.175

PONERT, J. (1973): Combinationes novae, stati novi et taxa nova non tantum specierum turcicarum. - Feddes Repert. 83(9-10): 617- 644.

PYŠEK, P. (1993): What do we know about Calamagrostis villosa? A review of the species behaviour in secondary habitats. - Preslia 65: 1-20.

RieziNG, N. (2013): Néhány ritkább orchidea előfordulása a Dunántúl északi részén. - Kitaibelia 18(1-2): 179-180.

RIPKOVÁ, S. and HAGARA, L. (2003): New, rare and less known macromycetes in Slovakia. I. - Ceská Mycol. 55: 187-200.

Ryvarden, L. and Melo, I. (2014): Poroid fungi of Europe. Synopsis Fungorum 31. - Fungiflora, Oslo, $455 \mathrm{pp}$.

Szczep Kows KI, A. (2010): Sarcodontia crocea (Polyporales, Basidiomycota) in Poland - distribution and decay ability in laboratory conditions. - Polish Bot. J. 55(2): 489-498.

SILLER, I. (1986): Nagygombák cönológiai vizsgálata rezervátum és gazdasági bükkös állományokban. - Mikol. Közlem., Clusiana 1986(2-3): 95-116.

SILLER, I. (2004): Hazai montán bükkös erdörezervátumok (Mátra: Kékes Észak, Bükk: Öserdö) nagygombái. - Manuscript, PhD Theses, Kertészettudományi (Multidiszciplináris Agrártudományok) Doktori Iskola, Budapest, 113 pp. 
Siller, I. and TURCSÁNYI, G. (2002): New and rare macrofungi species of two forest reserves in Hungary. - Fritschiana 42: 48-58.

Siller, I., Dima, B.. Albert, L., Vasas, G., Fodor, L., Pál-Fám, F., Bratek, Z. and Zagyva, I. (2006): Védett nagygombafajok Magyarországon. - Mikol. Közlem., Clusiana 45(1-3): 3-158.

Siller, I., Kutszegi, G., Takács, K., Varga, T., Merényi, Zs., Turcsányi, G., Ódor, P. and Dima, B. (2013): Sixty-one macrofungi species new to Hungary in Örség National Park. Mycosphere 4(5): 871-924, http://dx.doi.org/10.5943/mycosphere/4/5/3

Simon, T. (1992): A magyarországi edényes flóra határozója. Harasztok - virágos növények. [The identification book of the vascular flora of Hungary. Ferns and flowering plants]. - Tankönyvkiadó, Budapest, $892 \mathrm{pp}$.

Simon, T. (2000): A magyarországi edényes flóra határozója. - Nemzeti Tankönyvkiadó, Budapest, $976 \mathrm{pp}$.

Soó, R. (1966): A magyar flóra és vegetáció rendszertani-növényföldrajzi kézikönyve II. - Akadémiai Kiadó, Budapest, 655 pp.

SULYoK, J. (2011): Nőszőfü-fajok térképezése a Bükki Nemzeti Park Igazgatóság működési területén. - Zöld Horizont 6(2): 5.

SULYOK, J. (2012): Orchideák térképezésének tapasztalatai az Északi-középhegységben. - Kitaibelia 17(1): 58.

Szücs, P., József, J., PApp, V. G. and Kutszegi, G. (2015): A veszélyeztetett Anacamptodon splachnoides (Froel. ex Brid.) Brid. új adata a Bükk-hegységből. - Kitaibelia 20(2): 202-205. http://dx.doi.org/10.17542/kit.20.202

TAKÁcs, B. and Siller, I. (1980): A Bükk hegységi Ösbükkös gombái. - Mikol. Közlem.3: 121-132.

TATÁR, D. (1995): Két új nádtippan a magyar flórában: Calamagrostis villosa (Chaix) Gmel. és C. purpurea Trin. [Two new Calamagrostis species in the Hungarian flora: Calamagrostis villosa (Chaix) Gmel. and C. purpurea Trin.]. - Bot. Közlem. 82: 39-44.

Thiers, B. (2015+): Index Herbariorum: A global directory of public herbaria and associated staff. - New York Botanical Garden's Virtual Herbarium. http://sweetgum.nybg.org/ih/ (accessed: 03.11.2015)

Thongbai, B., Rapior, S., Hyde, K. D., Wittstein, K. and Stadler, M. (2015): Hericium erinaceus, an amazing medicinal mushroom. - Mycol. Progress 14: 91. http://dx.doi.org/10.1007/s11557-015-1105-4

VASAS, G. (2000): Contributions to the knowledge of macrofungi of the forests along the FeketeKörös, SE Hungary. - Studia bot. hung. 30-31: 79-86.

Vellinga, E. C. (2004): Genera in the family Agaricaceae: evidence from nrITS and nrLSU sequences. - Mycol. Res. 108: 354-377. http://dx.doi.org/10.1017/S0953756204009700

Venturella, G., Bernicchia, A. B. and Saitta, A. (2006): Three rare lignicolous fungi from Sicily (S Italy). - Acta Mycol. 41(1): 95-98. http://dx.doi.org/10.5586/am.2006.013

VlčKo, J., DítĚ, D. and KolNíK, M. (2003): Orchids of Slovakia. - ZO SZOPK Orchidea, Zvolen, $120 \mathrm{pp}$.

WatLing, R. (1988): Some British omphalinoid and pleurotoid agarics. - Notes Roy. Bot. Garden Edinburgh 45(3): 549-557. 